\title{
Pendidikan Karakter Yang Mengindonesia
}

\section{Oleh Nanang Bagus Subekti}

2015

Bab II tentang Dasar, Fungsi, Tujuan, khususnya Pasal 3 Undang-Undang Republik Indonesia Nomor 20 Tahun 2003 tentang Sistem Pendidikan Nasional, menyatakan

"pendidikan nasional berfungsi mengembangkan kemampuan dan membentuk watak serta peradaban bangsa yang bermartabat dalam rangka mencerdaskan kehidupan bangsa, bertujuan untuk berkembangnya potensi peserta didik agar menjadi manusia yang beriman dan bertakwa kepada Tuhan Yang Maha Esa, berakhlak mulia, sehat, berilmu, cakap, kreatif, mandiri, dan menjadi warga negara yang demokratis serta bertanggungjawab."

Pasal tersebut dengan sangat jelas menekankan pentingnya pendidikan watak atau karakter untuk membentuk manusia Indonesia seutuhnya. Ironisnya, kondisi di lapangan menunjukkan fakta belum maksimalnya ketercapaian tujuan pendidikan karakter.

Ada banyak kasus yang mencerminkan rapuhnya pendidikan karakter seperti kasus begal yang banyak melibatkan pelajar, banyak generasi muda yang menjadi korban narkoba, mahasiswi/siswi yang hamil di luar nikah akibat pergaulan bebas, kasus bocornya soal-soal ujian nasional (UN) yang menyuburkan budaya mencontek, tawuran antarpelajar, bullying di sekolah, dan berbagai kasus yang erat hubungannya dengan pendidikan karakter.

\section{Pendidikan Karakter dan Identitas Bangsa}

Pendidikan karakter berkaitan erat dengan identitas atau ciri khas bangsa Indonesia secara kolektif. Indonesia adalah Indonesia. Indonesia dengan keanekaragaman suku bangsa dan budayanya telah disatukan oleh moto Bhinneka Tunggal Ika, merupakan aset yang luar biasa.

Namun, seperti apakah karakter bangsa Indonesia yang sebenarnya? Menurut Kemendiknas, ada 18 karakter yang perlu diajarkan kepada para siswa yang meliputi: (1) religius, (2) jujur, (3) toleransi, (4) disiplin, (5) kerja keras, (6) kreatif, (7) mandiri, (8) demokratis, (9) rasa ingin tahu, (10) semangat kebangsaan, (11) cinta tanah air, (12) 
menghargai prestasi, (13) bersahabat/ komunikatif, (14) cinta damai, (15) gemar membaca, (16) peduli lingkungan, (17) peduli sosial, dan (18) tanggung jawab.

Nilai-nilai bangsa Indonesia sebenarnya sudah terumuskan dengan baik melalui Pancasila. Ironisnya, ajaran Pancasila seolah telah luntur dari berbagai tindakan, baik dalam konteks pendidikan formal maupun kehidupan berkewarganegaraan. Kita harus mau jujur bertanya, apakah lembaga pendidikan formal dan masyarakat Indonesia mengajarkan dan menerapkan nilai-nilai Pancasila dalam setiap sendi kehidupan?

\section{Trisentra Pendidikan}

Apa yang akan terjadi pada masa depan Indonesia jika karakter generasi mudanya rapuh? Sebagai orang tua, apakah yang dipikirkan jika generasi masa depan (baca: anak-anak) tidak tumbuh dengan karakter yang baik? Bagaimana jika anak-anak kita menjadi korban narkoba?

Bagaimana jika anak-anak tidak lagi mau mendengarkan ucapan kedua orang tua dan tidak ada lagi rasa hormat kepada kedua orang tuanya? Bagaimana jika anak-anak tumbuh dengan budaya bangsa lain karena hilangnya pengakuan kepada budaya sendiri?Jika dicermati lebih jauh, pendidikan formal telah memiliki banyak sekali pelajaran/materi budi pekerti, bahkan pendidikan karakter mulai terintegrasi dalam berbagai kegiatan sekolah.

Namun, mengapa di sana-sini masih terus terjadi berbagai permasalahan yang menunjukkan seolah pendidikan karakter belum sepenuhnya berhasil. Sebagai contoh, dalam pendidikan karakter, budaya tertib itu baik. Namun, dalam kehidupan sehari-hari ternyata tidak mudah menemukan pola kehidupan yang tertib seperti dalam budaya berlalu lintas.

Contoh berikut adalah adanya pelajaran bersih itu sehat, namun pada praktiknya dengan mudah kita jumpai masyarakat membuang sampah sembarangan. Lihatlah banyak sungai yang berisi tumpukan sampah. Kegagalan dalam pelaksanaan pendidikan karakter bisa jadi disebabkan oleh diri kita sendiri. 
Bisa jadi sampai saat ini sekolah masih bertepuk sebelah tangan, karena apa yang diajarkan di sekolah belum menjadi bagian budaya dalam kehidupan nyata masyarakat atau keluarga Indonesia. Jika demikian, rasanya tidak adil jika sekolah serta-merta dibebankan untuk membentuk sikap anak, namun di sisi lain keluarga (baca: orang tua) dan masyarakat tidak peduli dengan perkembangan karakter anakanak mereka sendiri.

\section{Momentum Peringatan Pendidikan Nasional 2 Mei}

Setiap 2 Mei Indonesia memperingati Hari Pendidikan Nasional (Hardiknas). Peringatan pendidikan nasional sebaiknya tidak hanya bersifat seremonial seperti upacara bendera, termasuk beberapa kegiatan demonstrasi yang berhubungan dengan pelaksanaan pendidikan nasional.

Namun, Hardiknas sebaiknya menjadi momentum refleksi pendidikan oleh seluruh komponen bangsa, baik para pelaku pendidikan maupun para stakeholder. Masa depan generasi muda tidak hanya ditentukan oleh pendidikan formal dalam hal ini sekolah/ kampus dan pengajarnya, tapi juga keluarga dan masyarakat. Perlu kesadaran bersama/ kolektif untuk memperbaiki karakter generasi muda Indonesia.

Kegiatan menuntut ilmu atau pendidikan sebaiknya menjadi kegiatan yang menyenangkan seperti yang dikonsepkan oleh Bapak Pendidikan Nasional Indonesia Ki Hadjar Dewantara (KHD). Hal ini berkali-kali ditekankan oleh Menteri Pendidikan dan Kebudayaan Anies Baswedan. Pengejawantahan pendidikan yang menyenangkan dan tidak memberikan banyak tekanan batin akan mampu menggerakkan hati dan pikiran siswa untuk meresapi apa yang dipelajari.

Sekolah adalah lembaga formal untuk mencerdaskan kehidupan bangsa. Sekolah harus memiliki daya tarik bagi para siswa. Pendidikan yang bersifat menjajah atau membelenggu hati dan pikiran siswa justru akan menjadi bumerang. Hati dan pikiran siswa yang terbelenggu akan terus memberontak sehingga kelak menghasilkan generasi yang hampa, karena mereka tidak mau mencerna dan menemukan makna dari setiap materi yang dipelajari di sekolah dengan baik. 
Akibatnya, setelah mereka lulus, nilai-nilai pendidikan karakter tidak akan tampak dalam perilaku, karena hati dan pikiran siswa telah tertutup untuk belajar. Hasil pendidikan tidak hanya diukur dari pengetahuan (kognitif), tetapi juga dari afektif dan psikomotoriknya atau dalam konsep pendidikan KHD adalah Ngerti (kognitif), Ngerasa (afektif), dan Ngelakoni (psikomotorik).

Bisa jadi selama ini proses pembelajaran baru sebatas teori atau formalitas saja, sehingga hasil praktik dalam kehidupan nyata belum maksimal, bahkan sangat jauh dari harapan. Konsep mendidik KHD yang menghamba pada sang anak sudah sepatutnya diterapkan dalam pendidikan formal dan nonformal untuk memberikan pendidikan yang bermakna, sehingga mimpi membentuk manusia Indonesia seutuhnya akan segera tercapai.

Artikel ini pernah diterbitkan di Koran SINDO

Senin, 4 Mei 2015 - 12:15 WIB, https://nasional.sindonews.com/read/996913/162/pendidikan-karakter-yangmengindonesia-1430716449 